\title{
Learners' Awareness towards the Use of MOOCs in Teaching and Learning
}

\author{
Rusreena Rusli, Haida Umiera Hashim, Harwati Hashim*, Melor Md. Yunus \\ Faculty of Education, Universiti Kebangsaan Malaysia, Bangi, Malaysia \\ Email: ^harwati@ukm.edu.my
}

How to cite this paper: Rusli, R., Hashim, H. U., Hashim, H., \& Yunus, M. Md. (2019). Learners' Awareness towards the Use of MOOCs in Teaching and Learning. Creative Education, 10, 3012-3019. https://doi.org/10.4236/ce.2019.1012225

Received: October 16, 2019

Accepted: November 26, 2019

Published: November 29, 2019

Copyright $\odot 2019$ by author(s) and Scientific Research Publishing Inc. This work is licensed under the Creative Commons Attribution International License (CC BY 4.0).

http://creativecommons.org/licenses/by/4.0/

(c) (i) Open Access

\begin{abstract}
In today's era of globalisation, Massive Open Online Courses (MOOCs) are no longer a stranger among universities and higher institutions. Many universities and colleges have started to make use of MOOCs as the platform for online learning in combination with face to face classroom for university courses. However, there are still many learners, especially university students who are not aware and familiar with the existence of Massive Open Online Courses (MOOCs). In conjunction to this, researchers intended to investigate students' awareness towards MOOCs and the use of MOOCs in teaching and learning in higher institutions. The respondents of this study involved university students from various public and private universities. The findings have gathered that majority of the students are fully aware of MOOCs' existence, its powers, benefits and what MOOCs can offer. Through the social learning aspects in MOOCs, students can empower to grow in knowledge, soft skills and personalities. In conclusion, it is believed that MOOCs can be utilised to help teachers and future teachers to cater many types of learners and their proficiency.
\end{abstract}

\section{Keywords}

Awareness, Higher Institutions, Massive Open Online Courses (MOOCs), Online Learning, Technology

\section{Introduction}

Digital learning is no longer a stranger among today's digital native. Undoubtedly today's generation of students would prefer the integration of technology and Information and Technology (ICT) in their learning session. Massive Open Online Course (MOOC) has been making its waves in the education field and their impacts have been acknowledged by people all around the world (Yunus, 
2018). Massive Open Online Course (MOOC) is a web-based course available for free to any participant from all around the world. MOOC is believed to be one of the recent innovations in education and has represented a current trend in online education (Hashim \& Yunus, 2018). Massive Open Online Course (MOOC) is currently widely used in tertiary level of education and has been the main preference among university educators and instructors (Yunus, Hashim, \& Hashim, 2019). Many educators prefer the integration of MOOC in combination with face to face classroom in their teaching and learning process. In conjunction to this, researchers intended to investigate students' awareness towards the use of Massive Open Online Course (MOOC) in their teaching and learning process.

\section{Literature Review}

Ostashewski et al. (2016) conducted a study on the use of MOOCs Interactions to engage students in university course activities. Their findings have presented that blended MOOCs with classroom-based does provide university students with personalised active learning opportunities. They also believed that online learning are able to help learners to be more meaningful. Hashim \& Yunus (2018) discussed the usefulness of Massive Open Online Courses (MOOCs) to develop students' communication skills in English language. They believed that the emergence of fourth industrial revolution has driven today's younger students to be able to equip themselves with good communication skills especially in English language. They have gathered that MOOCs are able to equip students with various resources and tools to help them to be more autonomous in their learning. They also believed that MOOCs are able to help students to create new and different opportunities for them to explore the knowledge on their own.

In another paper done by Hashim et al. (2019), they investigated students' acceptance and perceptions on the use of Massive Open Online Courses (MOOCs) in teaching and learning. They have gathered that Massive Open Online Courses (MOOCs) are able to help to provide students with more meaningful learning where the integration of ICT helps students to be more interactive and participative during the teaching and learning session. Students' acceptance towards the use of MOOCs can vary depends on their style of learning and preferences. These findings were also parallel to Verstegen et al. (2018)'s study on the use of MOOCs in helping learners to be collaborative in their learning. Verstegen et al. (2018) believed that MOOCs help to provide learners with the platform to be collaborative on the learning tasks but communication and technological skills are needed. It is undoubtedly proven that MOOCs are beneficial in providing both educators and learners with the skills of 21st century learning and also to prepare them with the fourth industrial revolution.

\section{Methodology}

This study used a mixed method design as a study design. Questionnaire was used as the instrument in this study. The questionnaire was adopted from "MOOC 
Readiness Questionnaire" by Prof Dr Mohammad Amin Embi for National Higher Education Strategic Plan. The questionnaire was divided into two sections which are section A which is the demographic and background of the respondents, and section B which is the respondents' awareness towards Massive Open Online Courses (MOOCs). The questionnaire was then distributed to random sampling respondents as the sample of this study. The samples of this study are among the university students from all public and private universities in Malaysia. The data collected then analysed with descriptive statistic using frequency and percentage counts.

\section{Findings and Discussion}

\subsection{Demographic Profile}

This research is participated by $60 \%$ of undergraduate students and $40 \%$ of them are the post-graduate students. Majority of them with $60 \%$ of percentage received are females and $40 \%$ of them are males. A total of twenty participants were involved in this study and they are from 5 public universities and one private university. The percentages of participants according to their institutions are IIUM (10\%), UKM (35\%), UM (10\%), UNISEL (20\%), UPSI (15\%) and UITM (10\%).

\subsection{MO0Cs Awareness}

\section{Q1: Are you aware of MOOC?}

Based on the pie chart above (Figure 1), we can see that there are equal percentages of MOOCs awareness from the Malaysian university students. There are $50 \%$ of students already aware of its existence and another $50 \%$ of students are not aware of MOOCs. The Malaysia MOOCs program was firstly introduced in September 2014. The official website for MOOCs named OpenLearning.com is open for all public institutions in Malaysia. Each courses offered under Malaysia MOOCs are facilitated by OpenLearning, which offers a learning framework that guides institutions to design their customised online courses (Ibrahim \& Rahim, 2018).

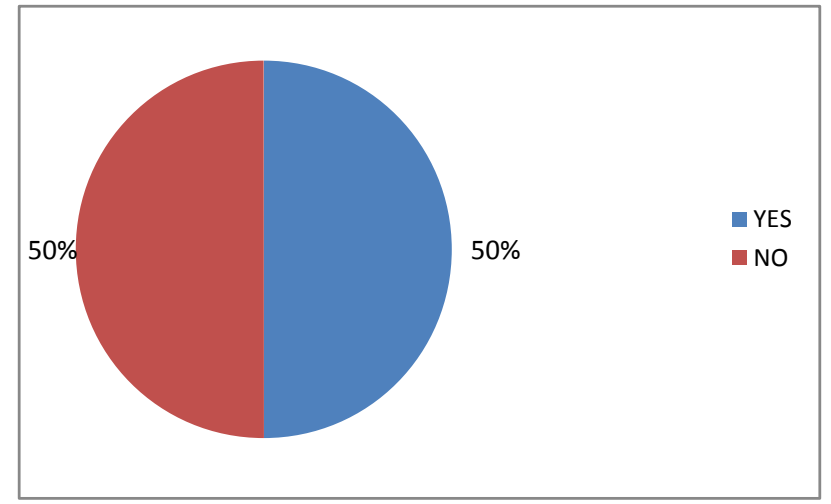

Figure 1. Percentages of MOOCs awareness from the Malaysian university students. 
These initiatives urged Malaysians to learn with different ICT devices and this may give positive effect to Malaysian students who compete with other developed countries. Thus, we can accept that MOOCs are slowly evolving and emerging in Malaysian higher education. In fact, MOOCs in Malaysia are expected to improve more in the future as we can foresee many contributions from higher education institutions because of the national objectives for MOOCs from the Malaysian government (Fadzil et al., 2015).

\section{Q2: If YES, what do you understand (your own conception) by MOOC?}

For the second question, the researchers asked for the participants' perception of MOOC. Based on their understanding, it can be summarized that MOOC is an open-based online platform that offered various courses for free that everyone from all over the world can choose and join. The participants also stated that MOOC is suitable for distance learning and also a good platform for $21^{\text {st }}$ century education. This is also supported by Nordin et al. (2015) who agreed that MOOCs to be accepted as technology for learning. Positive results from their findings are received from UTAUT factors such as performance and effort expectancy, social influence, behavioural intention, and facilitating conditions.

Besides that, MOOCs also supports blended learning to be executed effectively in education. As web based learning approach, MOOCs offer these advantages for Malaysia; 1) an intuitive and engaging delivery that promotes high-degree collaboration and international connections; 2) worldwide access to Malaysian expertise in niche regions; and 3) advance an open door for Malaysian higher education institutions to display their best programs and research areas (source: Ministry of Education Malaysia, 2014). As quoted by some of the participants,

"MOOC is an open online learning platform which offers a variety of courses for free"

"MOOC is an open-based online course that provides several e-learning courses for the students to choose according to their interest"

"Distance online learning"

"MOOC is an online platform for a 21 st century learning."

Q3: If your university plans to implement MOOC, how much of face-toface $(f 2 f)$ vs on line do you prefer?

Based on the bar chart (Figure 2), we can see that $55 \%$ of the participants preferred equal distribution of formal lessons and online classes. Meanwhile, $20 \%$ of the participants were choosing to have $70 \%$ face-to-face and $30 \%$ for online classes. Thus, we can conclude that the students are still preferring to maintain face-to-face lessons even though online platforms are utilised in the universities. This also concluded how face-to-face lessons are crucial and cannot be omitted in teaching and learning process. It will benefit both teachers and students if online courses are used for certain specific activities but not to be completely used as sole medium of learning.

Besides, online lessons also have its inconveniences. The absence of verbal and non-verbal interactions may decrease teacher-student communication in reality. 


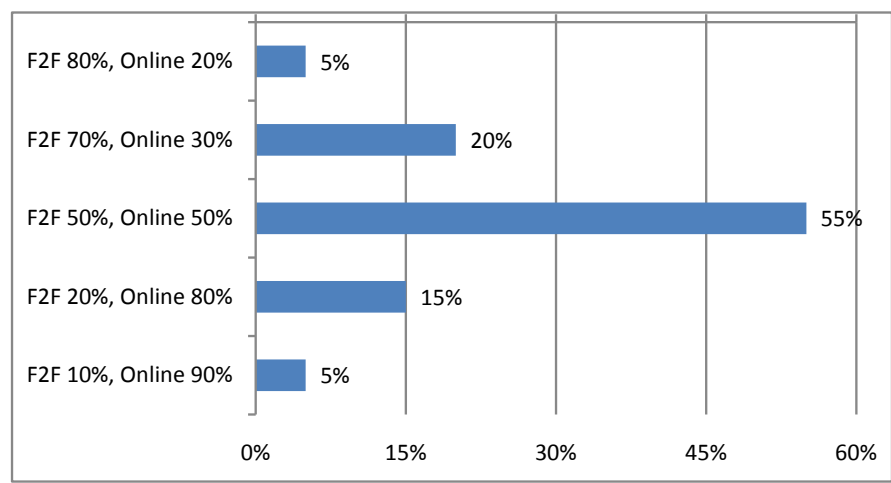

Figure 2. Preferred percentage of face-to-face (f2f) vs online.

Body language, voice intonation, facial expressions, gestures can help a student to learn how to communicate properly with others (Wright, 2017) and the lack thereof could be a factor for students to have communication issues in speeches, interviews and presentations. Thus, the perfect solution is to blend formal classes and online courses carefully to opt for effective educational settings (Rusli \& Hashim, 2018).

Q4: If your university plans to implement MOOC, what format do you prefer the teaching content to be made available online? (You may choose more than 1 answer)

Based on the bar chart (Figure 3), we can see that the highest percentage with $55 \%$ of participants preferred to have "text with video explanation" online. Next, the second highest response with $50 \%$ is for "Powerpoint with videos", followed by $45 \%$ responses for both "Animated Powerpoint" and "Powerpoint presentation only". The other choices of teaching contents received 30\%-35\% of preferences meanwhile the lowest percentage with $15 \%$ is for "text with audio explanation".

The affordances of having online courses utilization are that there are endless form of content and activities that can be practiced in teaching and learning. The usual texts and notes and be made more interesting with video features. A simple powerpoint presentations can no longer be less attended by students if they are filled with animated features and visuals. The act of sharing content is made easier with an online platform that students can always refer to. Teachers can no longer accept excuses from students of having their notes and exercises missing or left at home because their participations are accessible online. The developing accessibility of technology have opened up new types of learning content creation and conveyance that enable everyone to change where they learn which is anywhere and anytime (Hashim et al., 2017).

In addition, online learning can scale well, and it can give flexibility to access content and conveying assignments. New teaching methodologies that make better utilization of 1) video lectures and stored course materials and notes, 2) exercises for engaged learning for example, quizzes, games and interactive media content, and 3) social interactions with others through media channels and peer 
assessment give a potential model to powerful online learning (De Freitas et al., 2015).

Q5: If your university plans to implement MOOC, how often do you prefer to meet face-to-face with the course instructor/lecturer?

Based on the pie chart (Figure 4), we can see that majority of the participants with $65 \%$ responses preferred to have face-to-face lessons at least once a week if their university plans to implement MOOC. Meanwhile, 25\% of students chose to have a conventional lesson once every two weeks. It is believed that different level of students can bring different preferences of learning, such as post-graduate students are more keen towards online learning whereas undergraduates believed to opt better for face-to-face learning.

Face-to-face learning has been the standard for such a long time, it is usually perceived as the "genuine" method for learning. Since people must be physically present to take a conventional course, it is expected that they are using more effort and more serious in learning. In the meantime, taking a class face to face does not generally ensure that a person will be progressively engaged or successful. Online learning is not just an incredible option, yet it can likewise enhance face-to-face learning. Many teachers opted for a blended approach where both methods are combined to maximize learning benefits. Blended courses are

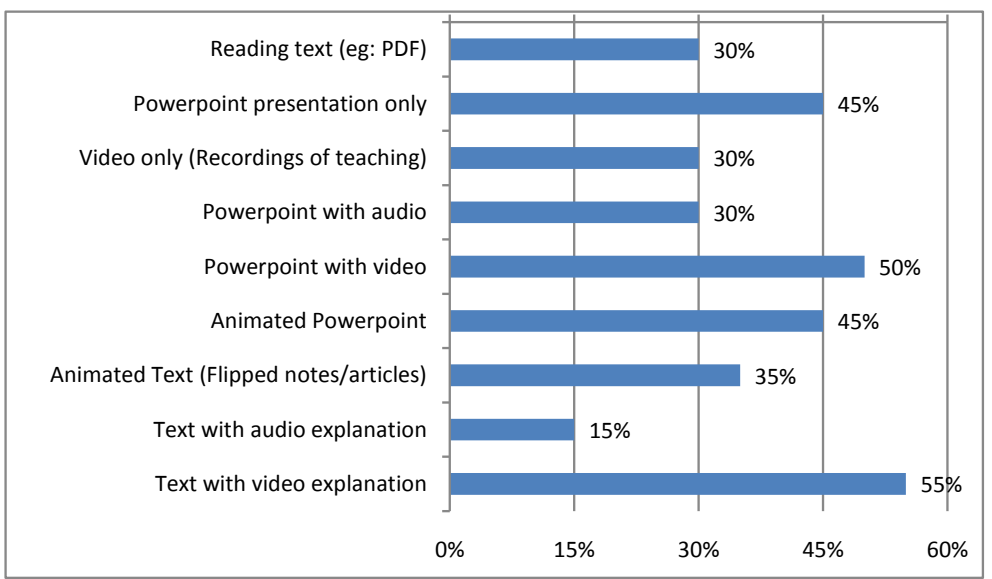

Figure 3. Preferred format of teaching content to be made available online.

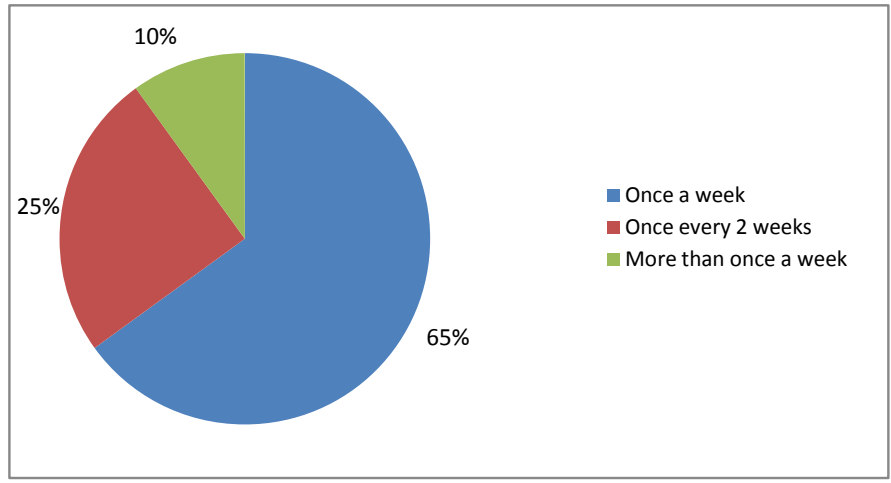

Figure 4. Percentage of to meet face-to-face with the course instructor/lecturer. 
highly promising in education. Teachers need to keep up a reasonable harmony between online and $\mathrm{f} 2 \mathrm{f}$ learning to permit teachers with adequate practice in using technology and suitable online content (Saltan, 2017).

Findings by Furio et al. (2015) revealed a small difference in the acquired knowledge of utilizing both face-to-face and online learning approach. The students recalled a great deal of the learning transmitted in face-to-face lessons and they used their knowledge to participate in the online learning content. However, there is no huge significant difference found between the two learning techniques. In sum, students accomplished similar knowledge improvements when using both face-to-face and online learning. Teachers need to implement online learning for $21^{\text {st }}$ century learning but cannot disregard the importance of having face-to-face learning.

\section{Conclusion}

MOOC has been the front of the educational technology in Malaysia. Students from all level of study can take MOOCs from various institutions on the platform, supporting cross-disciplinary and cross-institutional learning. In this paper, researchers have investigated the awareness of MOOCs by higher institution students in Malaysia. Majority of them are fully aware of MOOC existence, its powers, benefits and what it can offer. Through the social learning aspects in MOOC, students can empower to grow in knowledge, soft skills and personalities. Furthermore, Malaysia MOOCs have prepared and aimed for all the higher institutions to use the platforms to deliver teaching in line with the Malaysian Education Blueprint objectives. MOOC can be utilized to help teachers and future teachers to cater many types of learners and their proficiency. Future research can enrich the current knowledge by investigating the factors contributing to MOOCs awareness. All in all, teaching and learning nowadays should be engaging and has interesting features to maintain the generation $\mathrm{Z}$ students' interest in education.

\section{Funding}

This project was supported by Universiti Kebangsaan Malaysia grant KRA-2018044 and PP-FPEND-2019.

\section{Conflicts of Interest}

The authors declare no conflicts of interest regarding the publication of this paper.

\section{References}

De Freitas, S. I., Morgan, J., \& Gibson, D. (2015). Will MOOCs Transform Learning and Teaching in Higher Education? Engagement and Course Retention in Online Learning Provision. British Journal of Educational Technology, 46, 455-471. https://doi.org/10.1111/bjet.12268

Fadzil, M., Latif, L. A., \& Azzman, T. A. M. T. M. (2015). MOOCs in Malaysia: A Prelim- 
inary Case Study.

Furio, D., Juan, M. C., Seguí, I., \& Vivó, R. (2015). Mobile Learning vs. Traditional Classroom Lessons: A Comparative Study. Journal of Computer Assisted Learning, 31, 189201. https://doi.org/10.1111/jcal.12071

Gamage, D., Perera, I., \& Fernando, S. (2016). MOOCs to Provide 21st Century Skills: Learner Perspective. In 10th International Technology Education and Development Conference. https://doi.org/10.21125/inted.2016.0940

Hashim, H. U., \& Yunus, M. M. (2018). Digital Learning with Massive Open Online Courses (Moocs): English for Communication. http://www.mjltm.cominfo@mjltm.org

Hashim, H., Yunus, M. M., Embi, M. A., \& Ozir, N. A. M. (2017). Mobile-Assisted Language Learning (MALL) for ESL Learners: A Review of Affordances and Constraints. Sains Humanika, 9, 45-50. https://doi.org/10.11113/sh.v9n1-5.1175

Ibrahim, M. M., \& Rahim, M. K. I. A. (2018). MOOCs Continuance Intention in Malaysia: The Role of Interactivity and Enjoyment. Journal of Global Business and Social Entrepreneurship, 4, 114-121.

Nordin, N., Norman, H., \& Embi, M. A. (2015). Technology Acceptance of Massive Open Online Courses in Malaysia. Malaysian Journal of Distance Education, 17, 1-16. https://doi.org/10.21315/mjde2015.17.2.1

Ostashewski, N., Howell, J., \& Dron, J. (2016). Crowdsourcing MOOC Interactions: Using a Social Media Site cMOOC to Engage Students in University Course Activities.

Rusli, R., \& Hashim, H. (2018). Implementing an Online Learning Platform in an English as a Second Language Context: Analyses of Blended Courses Issues and Solution. International Journal of Engineering \& Technology, 7, 65-68.

Saltan, F. (2017). Blended Learning Experience of Students Participating Pedagogical Formation Program: Advantages and Limitation of Blended Education. International Journal of Higher Education, 6, 63-73. https://doi.org/10.5430/ijhe.v6n1p63

Verstegen, D., Dailey-Hebert, A., Fonteijn, H., Clarebout, G., \& Spruijt, A. (2018). How Do Virtual Teams Collaborate in Online Learning Tasks in a MOOC? International Review of Research in Open and Distributed Learning, 19, 39-55. https://doi.org/10.19173/irrodl.v19i4.3528

Wright, B. M. (2017). Blended Learning: Student Perception of Face-to-Face and Online EFL Lessons. Indonesian Journal of Applied Linguistics, 7, 64-71. https://doi.org/10.17509/ijal.v7i1.6859

Yunus, M. M., Hashim, H. U., \& Hashim, H. (2019). Massive Open Online Courses: En Route to Communication Skills Acquisition. Arab World English Journal (AWEJ) Special Issue on CALL, 5, 98-109. https://doi.org/10.31235/osf.io/xez9k 